\title{
Corrigendum
}

\section{Phenotypic recurrent selection for $2 n$ pollen and $2 n$ egg production in diploid alfalfa}

\section{S. Tavoletti ${ }^{1}$, A. Mariani ${ }^{1} \&$ F. Veronesi ${ }^{2}$}

${ }^{1}$ Instituto di Recerche sul Miglioramento Genetico delle Piante Foraggere, C.N.R., Perugia, Italy;

${ }^{2}$ Instituto di Produzione Vegetale, Università degli Studi di Udine, Udine, Italy

Euphytica 57: 97-102, 1991.

(C) 1991 Kluwer Academic Publishers. Printed in the Netherlands.

Owing to an error in the proof-reading process Table 4 of this article has been published incorrectly. The Table with the correct numbers is presented below.

Table 4. Selection for $2 \mathrm{n}$ egg production: effect of phenotypic recurrent selection on the average seed set per population and on the range of the seed per plant

\section{$2 \mathrm{x}-4 \mathrm{x}$ crosses}

Unselected population

$\left(\mathrm{B}_{0}\right)$

N. of plants utilized

$\mathrm{N}$. of flowers pollinated

$\mathrm{N}$. of seeds produced

Average seed set (\%) ${ }^{1}$

Seed set per plant (\%) (Range)

Population of the 1st cycle

(B)

Population of the 2nd cycle $\left(B_{2}\right)$

$\begin{array}{ccc}16 & 139 & 101 \\ 563 & 5347 & 2469 \\ 26 & 613 & 652 \\ 4.26 \mathrm{a} & 11.46 \mathrm{~b} & 26.4 \mathrm{c} \\ (0-96) & (0-75) & (0-160)\end{array}$

${ }^{1}$ Average seed set $=(\mathrm{N}$. of seeds produced $/ \mathrm{N}$. of flowers pollinated $) \times 100$; means not followed by the same letter differ significantly at $P \leq 0.01$. 